\title{
The ECB's Monetary Dialogue with the European Parliament: Efficiency and Accountability during the Euro Crisis?*
}

\author{
STEFAN COLLIGNON ${ }^{1,2}$ and SEBASTIAN DIESSNER ${ }^{2}$ \\ ${ }^{1}$ Sant'Anna School of Advanced Studies Pisa ${ }^{2}$ London School of Economics and Political Science
}

\begin{abstract}
The monetary dialogue between the European Parliament and the European Central Bank (ECB) is a key component for the democratic accountability of the independent central bank. We provide new evidence for the efficiency of the dialogue and present the results of a survey conducted amongst the members of the parliament's ECON (economic and monetary affairs) committee. We find that while the monetary dialogue may have had little or even a negative impact on financial markets, it plays a significant role in informing and involving members of parliament and their constituencies. Amidst an intensifying debate about the communication and transparency of the ECB, these findings shed new light on the current state of affairs of ECB accountability and its alleged need for enhancement.
\end{abstract}

Keywords: european central bank; accountability; eurozone crisis; european parliament; monetary dialogue

\section{Introduction}

Central bank communication is crucial for the effectiveness of monetary policy. Central banks affect the economy by setting interest rates and conducting money market operations, but also through their influence on expectations (Woodford, 2005). To be effective, central banks' interventions, signals and policy discourses must remain coherent over time so that the contexts and reasons for which the central bank takes certain actions are properly understood by economic agents and the public at large. Policy consistency is supported by central bank independence, which prevents unwarranted interferences with the conduct of monetary policy. Yet, while central bank independence is a necessary condition for coherence in monetary policy, it is not sufficient: when responding to changes in the environment, the central bank must not only convey a reaction in its policy stance, such as adjusting interest rates, but also explain how it pursues its goals by appropriate action. Ultimately, policy effectiveness also rests on the democratic legitimacy of the central bank as an institution that serves collective welfare. These needs assign, in theory, a two-fold function to the transparency and accountability of central bank communication: they ought to further both the effectiveness and the democratic legitimacy of monetary policy.

In the euro area, monetary policy responsibility has been delegated to the highly independent ECB (European Central Bank), while other policy competences have remained

\footnotetext{
*We thank Piero Esposito for research assistance on an earlier version of the article which formed part of the EP research note IP/A/ECON/NT/2014-01 in the compilation PE 518.753. We are highly grateful to colleagues from LSE and Sant'Anna as well as three anonymous reviewers for their very helpful comments. All errors remain our own.
} 
under the control of member states. Given that there is no institution to correct inconsistencies in the conduct of decentralized national economic policies with respect to the aggregate macroeconomic policy stance, the communication, transparency and accountability of the central bank is even more important than in sovereign nation-states. Such policy inconsistencies have been at the root of the euro crisis and have made a subsequent return to sustainable balanced growth and full employment more difficult. The ECB, as the only unified macroeconomic actor, has played a major role in preserving the euro as the single currency, while national politics have frequently been a source of uncertainty and economic shocks (Collignon et al., 2013). In this context, communication between the ECB and political decision-makers has been indispensable, but the problems are compounded by the fact that decision-makers are not only national governments but voters in national constituencies. While the eurogroup allows the direct exchange of views between the ECB president and finance ministers, the legitimacy and general acceptance of the euro requires that the public at large is able to comprehend and challenge the views of the central bank. Yet while the ECB communicates regularly through press conferences, public speeches and official documents, the only institutional setting for a mutual exchange with the representatives of eurozone citizens is the quarterly MD (monetary dialogue) between the EP's (European Parliament) ECON (economic and monetary affairs) committee and the ECB president. This raises the question whether the MD has contributed to a better understanding of economic and monetary policy requirements in the context of the rapidly deteriorating euro crisis.

This article assesses, therefore, the role of the MD during the EP's seventh legislative term (2009-14). We conduct an empirical test of the two functions that can theoretically be assigned to central bank communication in the MD, namely, monetary policy efficiency and democratic accountability. To this end, we employ a set of both quantitative and qualitative methods: policy efficiency is gauged with the help of an econometric GARCH-M model, while accountability is examined through a close reading of policy transcripts as well as parts of an own survey amongst policy-makers. Our findings suggest that the dialogue's impact on monetary policy efficiency is small at best, but that its accountability function is all the more relevant. The rest of the article is structured as follows. We first review why central bank communication and accountability are important especially during times of crisis and derive two hypotheses from the academic literature. We then produce evidence with respect to the impact the dialogue has had on financial market reactions, changes in the quality of exchanges during the crisis and the views MEPs (Members of the European Parliament) as representatives of citizens have themselves about the usefulness of the dialogue. We conclude that while the exchanges between the two institutions seem to have done very little to improve the stability of financial markets, they do play a role in informing and involving members of the parliament and thus further the ECB's democratic accountability.

\section{Central Bank Communication and Accountability in Times of Crisis}

Since the global financial crisis erupted in 2008, parts of the received wisdom on monetary policy-making have been shaken. While the debate about policy objectives used to focus on the trade-off between inflation and unemployment, it is now understood that conventional monetary policy must be grounded in financial stability. Focusing on 
medium-term price stability - supported by central bank independence, accountability and clear communications - was by itself not enough to guarantee financial stability (Vayid, 2013). The source of financial instability resulting in the global financial crisis was the build-up of asset price misalignments (bubbles), which had generated asset overvaluations and persistent debt accumulation. In principle, the ECB could have prevented credit bubbles by controlling monetary and credit aggregates in the monetary pillar of its strategy framework (and indeed it was more conservative than the Federal Reserve System under Greenspan). In reality, however, it is difficult to detect the early stages of a bubble and in the euro area asset bubbles were localized in some member states. Like other central banks prior to the crisis, the ECB had given priority to inflation targeting of consumer prices and excluded asset prices from its policy focus. If this was a mistake, it was shared with the EP: before the Lehman crisis the ECON committee did not press the ECB to explain asset price inflation. However, during the seventh parliament, the committee did raise the issue during almost every session, although the ECB's answers have remained evasive.

The crisis has generated new challenges for monetary policy, which also affect the ECB's accountability. First of all, the question arises of how the central bank ought to deal with financial instability. Central banks around the world responded by cutting interest rates and accommodating the high liquidity preference of banks. Initially, the euro area's other major institutions were slow to seize the full policy implications of the crisis. Observing large current account imbalances, the European Commission and Council of the EU focused on old-fashioned structural policies, and through the tightening of fiscal rules and the creation of the macroeconomic imbalance procedure austerity was imposed as a response to the debt crisis, while financial markets were heading to a meltdown with massive fire sales re-enforcing the dynamics of financial instability. The disaster was only avoided when the ECB explicitly acknowledged that maintaining financial stability was one of its objectives and President Draghi famously pledged that the ECB would 'do whatever it takes to preserve the euro' (ECB, 2012). In practical terms, the ECB reacted not only by cutting interest rates but also by means of unconventional policies, namely, by providing ample liquidity through its long-term refinancing operations, by open market purchases under the securities market programme and finally by setting up the unlimited OMT (outright monetary transactions) programme.

Second, the crisis has posed new questions for the future conduct of monetary policy: should the ECB address financial imbalances and asset price misalignments preemptively (that is, 'lean against the wind', as former ECB president Jean-Claude Trichet proclaimed in front of the MD (European Parliament, 2010)) or rather clean up after they unwind? As Europe is painfully learning now, unwinding imbalances involves extensive and lengthy debt deleveraging associated with persistently weak demand, low growth, rising unemployment and fiscal constraints (Vayid, 2013, p. 21). The implications of these developments and the question of how financial stability should be integrated into monetary policy are still under debate. The creation of a banking union with particular focus on macro-prudential supervision, in the form of the European Systemic Risk Board and the banking union's single supervisory mechanism which are both located at and operated by the ECB, has elevated the role of the central bank in general and is likely to generate new requirements for its communication and accountability in particular (Pisani-Ferry and von Weizsäcker, 2009). It thus appears evident that a closer look at the theory and 
practice of existing provisions for ECB communication and accountability, as well as their usefulness in the new post-crisis environment, is warranted. In the following, we provide a discussion of these aspects with the aim of deriving testable hypotheses on the potential impacts of the MD.

\section{Parliamentary Scrutiny of Central Banks and its Impact on Monetary Policy Efficiency}

The academic literature distinguishes between central bank transparency and accountability. Transparency is the broader concept and it encompasses all forms of communication about the conduct of monetary policy. It includes a clear legal mandate, setting up a coherent strategic and operating framework, the publication of forecasts and sometimes also the publication of internal records on the debates in the policy-making bodies. In addition to these structural arrangements, transparency requires frequent communication to financial markets and to the general public (Eijffinger and Geraats, 2006). The ECB does this through its press conferences after board meetings, the monthly bulletin (since 2015 replaced by a six-weekly economic bulletin), its annual report, the financial stability report, published research including forecasts, and the frequent speeches by its staff and directors. Crowe and Meade (2008) suggest that, on the whole, this endows the ECB with a higher degree of transparency than the majority of national central banks had exhibited prior to the establishment of the eurosystem.

Accountability, on the other hand, means explaining and justifying policy decisions ex post, that is, by making clear why the ECB did what it did and why the measures taken may or may not have achieved their purpose. If transparency helps clarify and explain policy decisions, it is often seen as furthering accountability in a non-substantive manner. ${ }^{1}$ Moreover, with unconventional policies, ex ante explanations, or forward guidance, have become important areas where transparency and accountability overlap. The ECB effectively started providing such forward guidance in July 2013, by giving an indication of the future path of its policy interest rates (ECB, 2014). This generates new demands on the bank's accountability. In the future, communicating and clarifying a convincing exit strategy from unconventional monetary policies without creating further instability in financial markets will be one of the greatest challenges.

Central bank accountability is always geared towards democratically elected representatives, either parliaments or governments. Stasavage (2003) has studied the arrangements in 44 countries and found 32 had a specific requirement for central bank officials to testify before a national parliament on a regular basis. However, in some countries there were also provisions for governments to override central bank decisions. The literature has emphasized that transparency and accountability might improve the efficiency of monetary policy (cf. Geraats, 2008) although it has been argued as well that if accountability includes a publication of the dispersed views of individual decision-makers or a possibility of overriding the central bank, it might be counterproductive (Gersbach and Volker, 2008; Ehrmann and Fratzscher, 2013). The latter view serves to understand why the ECB has been given both instrument and goal independence, which means that it can determine

\footnotetext{
${ }^{1}$ Some confusion may arise from the literature here, as authors seem to invoke the labels 'formal accountability' (Buiter, 2006; Sibert, 2010) and 'informal accountability' (De Grauwe, 2012) for the exact same issue of relying on transparency as a voluntary means to enhance accountability.
} 
the quantitative benchmarks for its primary objective as well as the instruments with which to attain them.

In line with these considerations, we hypothesize that the transparency and accountability of ECB monetary policy, as professed in the MD, could potentially reduce the cost of economic adjustment in the crisis. The alternative hypothesis would be that some forms of communication may at times raise volatility and uncertainty, expressed as increases in bond yields due to a higher risk premium (indeed a very common hypothesis in economics). Enhanced transparency can improve the efficiency of monetary policy by calming financial markets, for instance, by reducing volatility and uncertainty especially in sovereign bond markets so that the monetary transmission process is enhanced. ${ }^{2}$ There is, however, also the possibility that an increased transparency raises the awareness for sovereign default risks, so that bond yields rise when uncertainty is reduced. In this case, monetary policy becomes less efficient because financial markets become more fragmented. The first hypothesis that we aim to examine therefore reads:

$H 1$ : The monetary dialogue has enhanced the efficiency of ECB monetary policy during the crisis by reducing volatility and uncertainty in sovereign bond markets.

Hypothesis 1 can be formally tested. Volatility is measured by analysing the conditional variance in yields, depending on the variance of previous periods, as performed by standard GARCH models (cf. Enders, 2004). One can, however, also measure the direct impact on yields or changes of yields (that is, their acceleration) with the help of GARCH-M models which estimate simultaneously the mean bond yield and the conditional variance. To test hypothesis $\mathrm{H} 1$, we estimate a GARCH-M model for changes in bond yield spreads of the five major crisis countries (Greece, Ireland, Italy, Portugal, Spain) on a dummy variable where the day of the MD takes the value 1 and all other days are 0 . Hence, the dependent variable of interest is the first difference of daily bond yields. We measure the dialogue's aggregate effects on the rate of change of spreads and on the volatility in the bond market over three days after each appearance of the ECB president before the ECON committee.

The literature gives an indication of the expected impact of transparency on the efficiency of monetary policy. Jansen and de Haan (2007) found that ECB verbal interventions have had little effect on the value of the euro in normal times, whereas Rosa and Verga (2007) showed that the introductory statements of the then-monthly ECB press conferences have had an impact on market behaviour and expectations. Born et al. (2012, 2014) found that while published financial stability reports tend to reduce volatility in financial markets, speeches and interviews increase volatility and uncertainty. Collignon et al. (2013) worked out that speeches by the German chancellor Merkel have increased uncertainty during the crisis and pushed up the spreads for Greek bond yields. Stasavage's (2003) aforementioned analysis estimated the relation between transparency, accountability and the cost of disinflation. The author found significant effects for the reduction of these social welfare costs with respect to forecast transparency, the possibility of governments overriding central banks and wage coordination. However, most

\footnotetext{
${ }^{2}$ One could, moreover, frame this as a form of 'output legitimacy', because more efficiency in the conduct of monetary policy may increase the acceptance of the institution (cf. Scharpf, 1999; Begg, 2006).
} 
interestingly, reporting to the legislature was always found to be statistically insignificant and had a positive cost-increasing sign in high-income OECD (Organisation for Economic Co-operation and Development) countries. This result ought to encourage modesty and keep us from exaggerating the role of the MD. We are not aware of any formal estimates of the MD's impact on financial markets to date.

\section{Assessing Democratic Accountability: ECB-EP Relations in the Monetary Dialogue}

It has been affirmed many a time that the ECB is one of the most independent central banks in the world and that it has, therefore, a particular responsibility for ensuring transparency and accountability in the conduct of its policies (De Grauwe, 2012). Central bank independence is often criticized as undemocratic, for it imposes constraints on the sovereignty of states (cf. Baimbridge et al., 1999). This argument applies to independent national central banks as much as to the ECB: if the central bank can refuse to monetize public debt in order to maintain low inflation, the sovereignty of governments is no longer absolute. Yet, while technically the ECB only has a limited task as the bank of banks which alone supplies the legal tender currency (Goodhart, 1987), it has a clear political mandate for maintaining price stability as the primary policy objective. Subject to fulfilling this highest ranking objective, the ECB is also tasked with supporting other economic policies (Art. 127(1) TFEU - Treaty on the Functioning of the European Union). As in all instances of delegated tasks, there is always a question whether an agent, in this case the central bank, makes enough efforts to achieve its mandated purposes (Pollack, 1997; Majone, 2001a, 2001b). It is, therefore, one of the noblest tasks of the EP to hold the ECB to account and check if and how it fulfils its mandate.

A prudent approach to central bank accountability should reflect that there may not be one ideal-type strategy of central bank communication, but that each central bank may identify the channels of accountability and transparency it deems best for consistent policy-making (Ehrmann and Fratzscher, 2007). The ECB, the world's first and only supranational central bank, is surely no exception here. Jabko (2003) and Torres (2013) have emphasized the potential and actual merits of the EP's MD with the ECB as its own resource of democratic legitimacy. In a democratic society as diversified as the euro area's, there naturally appears to be a need for plurality in (expert) opinions, challenges of views and questioning of orthodoxies to be part of the process by which the ECB is held to account. This diversity is deeply reflected in the EP, and in fact more so than in other European institutions. It is precisely for this reason that one would deem the MD to be of importance: the need to respond to the concerns of citizens in their respective constituencies can anchor the ECB in society, generate a public sphere, and increase the acceptability and legitimacy of European institutions. Conversely, the EP may itself be a driver in making the ECB more transparent as it has, in the past, demanded and obtained the publication of forecasts from the central bank.

While the ECB is independent and member states are autonomous (albeit fiscally constrained by an ever closer net of rules), the MD is one of the few bridges to link monetary policy with other policy considerations. Formally, the dialogue was set up by the EP's resolution on 'democratic accountability in the third phase of EMU' of 4 May 1998 which called for the organization of a dialogue between the EP and the future ECB on monetary and economic affairs, the framework for which was confirmed by mutual 
agreement (European Parliament, 1998). Although the Treaty requires only one meeting a year, the MD takes place effectively at least four times a year in the form of debates between the ECON committee and the president of the ECB. This frequency exceeds the average appearances by other central banks before their parliaments (Eijffinger and Mujagic, 2004). Prior to the meetings of the dialogue, two subjects are usually identified for discussion and an expert panel is requested to submit notes as background information. During the formal session, the president is first asked to give a short introductory statement and then he replies to questions from MEPs which do not necessarily stick to the previously identified subjects. Over the years, the time allowed for the initial statement has been shortened in order to give MEPs the opportunity to ask more questions. Along the lines of these general considerations, the second hypothesis of our article reads:

$H 2$ : The monetary dialogue has served as a means of democratic accountability of ECB monetary policy during the crisis.

Evaluating the impact the MD has had in terms of democratic accountability is difficult, because the contents and consequences of a discussion may be diffuse and because the ECB does not take any instructions from European or national institutions. Earlier assessments of the MD have often been critical, observing a lack of forcefulness and qualification of MEPs; a tendency to talk cross-purpose; the absence of common grounds or concerns between ECB and EP, reinforced by the large size of the ECON; and the ECB's discursive monopoly on most issues (De Grauwe and Gros, 2009; Amtenbrink and Van Duin, 2009; Wyplosz, 2005; Sibert, 2005; Gros, 2004). Nevertheless, in their study of previous parliaments, Eijffinger and Mujagic (2004) have claimed that in 71 per cent of the cases the ECB had implemented changes requested by the ECON, and that the transmission from the panel of economic experts to ECON was equal to 100 per cent. Sibert (2005) also finds some evidence that the ECON committee was more successful in influencing monetary policy when it was in line with the expert panel advising it.

We seek to operationalize and measure the democratic accountability of ECB monetary policy through the MD along two different dimensions. On the one hand, we undertake a qualitative assessment of debates in the MD over the entire course of the seventh parliament, juxtaposing some salient exchanges between former ECB president Jean-Claude Trichet and the ECON committee in opposition to those between current president Mario Draghi and the very same parliamentarians. The aim is to gain a sense of how the style and content of the often diffuse debates in the MD may have evolved throughout the crisis years with a view to the readiness of the ECB to answer specific questions posed by MEPs. To this end, we can rely on the verbatim transcripts of all MD sessions which are publicly available through the EP but which have been paid relatively little attention to in the academic literature. On the other hand, we invoke survey data from a larger review that we have conducted amongst parliamentarians in the ECON committee to gauge their sense of the role the MD plays in involving them in ECB monetary policy-making, focusing in particular on the survey items that asked committee members about the perceived usefulness of the dialogue both in terms of the management of the eurozone crisis and in terms of informing them as representatives of the general public. The rationale behind this two-fold research strategy is to not only look at what the available textual data (that is, the transcripts of the MD) might reveal, but also to 
Table 1: Estimation of Monetary Dialogue's Impact on Spreads and Volatility in Crisis Countries

\begin{tabular}{lllrr}
\hline & Coefficient & Std. error & z-Statistic & Prob. \\
\hline Greece & & & & \\
$\quad$ Spread & 0.1020 & 0.0469 & 2.1734 & 0.0298 \\
$\quad$ Spread (-1) & 0.0805 & 0.0321 & 2.5086 & 0.0121 \\
$\quad$ Volatility (-1) & -0.0473 & 0.0140 & -3.3660 & 0.0008 \\
$\quad$ Volatility (-2) & -0.0868 & 0.0008 & -112.2873 & 0.0000 \\
$\quad \begin{array}{l}\text { Ireland } \\
\quad \text { Spread }\end{array}$ & 0.0401 & 0.0110 & 3.6431 & 0.0003 \\
$\begin{array}{l}\text { Portugal } \\
\quad \text { Spread }\end{array}$ & 0.0309 & 0.0146 & 2.1215 & 0.0339 \\
$\quad$ Volatility (-2) & 0.0054 & 0.0023 & 2.3091 & 0.0209 \\
$\quad \begin{array}{l}\text { Spain } \\
\quad \text { Spread }\end{array}$ & 0.0206 & 0.0096 & 2.1534 & 0.0313 \\
$\quad$ Italy & & & \\
$\quad$ Volatility & 0.0016 & 0.0004 & 3.5425 & 0.0004 \\
\hline
\end{tabular}

try and extract some information from the very producers of this textual data, namely, the parliamentarians in the ECON committee. ${ }^{3}$ We are confident that this approach can at the very least give an indication of the ECB's accountability towards the ECON in the crisis, bearing in mind that determining a precise 'degree' of accountability is impossible.

\section{The Impact of the Monetary Dialogue on ECB Monetary Policy Efficiency}

What effect did the MD have during the euro crisis? In this section, we present some econometric evidence for the impact of the MD on financial markets and the transmission of monetary policy. As discussed above, the efficiency-enhancing effect of the MD can be measured by the contribution it may have made towards reducing volatility in sovereign bond markets. Standard economic theory would assume that bond yields increase with rising default risks and increased uncertainty (measured by volatility). Employing the aforementioned GARCH-M model to test hypothesis $\mathrm{H} 1$, we would expect that in the day(s) after the MD the volatility in yield spreads of the five crisis countries (Greece, Ireland, Italy, Spain, Portugal) to be reduced and spreads to come down or at least their increases to slow down. However, our results do not confirm the hypothesis of a stabilizing effect (see Table 1 and Figure 1). ${ }^{4}$

First of all, the dynamics are different in the five countries. In Greece, we find significant effects on spread and volatility lasting for two days with spreads increasing and volatility decreasing. In Portugal both spreads and volatility are increasing. In Ireland and Spain volatility is not significant, but spreads are rising, while in Italy only volatility increases. These results may suggest that the MD did not significantly affect uncertainty in countries where problems were caused by real estate debt rather than by public

\footnotetext{
${ }^{3}$ For a similarly motivated research design, see Schonhardt-Bailey's (2013) intriguing study of United States monetary policy-making and parliamentary scrutiny as performed by the FOMC (Federal Open Market Committee) and the United States Congress, respectively.

${ }^{4}$ More detailed tables with coefficients for each of the five crisis countries are provided in the supporting information. Where the estimates were statistically not significant (at the 5 per cent level) the measured coefficients have been discarded.
} 
Figure 1: Estimation of Monetary Dialogue's Impact on Combined Spreads and Volatility in Crisis Countries

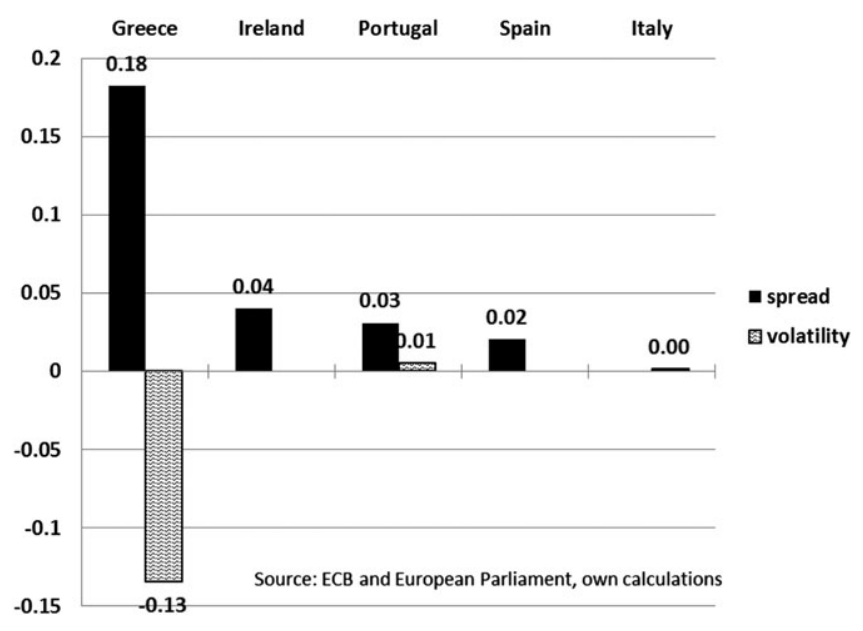

borrowing, such as Ireland and Spain, while it had a significant effect in countries with unsustainable public debt. Interestingly, in Greece increased transparency has pushed up the risk premia on sovereign debt. On the whole, these results do not support the hypothesis that the MD has increased the efficiency of monetary policy - if anything it has reinforced financial fragmentation. Yet, the barely significant and cost-increasing effect of the MD in the short term is generally consistent with the studies by Stasavage (2003), Jansen and de Haan (2007), Born et al. (2012, 2014) and Collignon et al. (2013) which all found that statements by public authorities alone rarely calm markets. Actions do. The ECB prevented the collapse of the euro in 2012 because it was credible in flooding banks with liquidity and setting up formal mechanisms for intervening in the markets. The implication of this result is that the MD does not markedly enhance economic efficiency by influencing financial markets in the short run. ${ }^{5}$ Its main function may then rather consist in providing democratic accountability to the elected representatives of European citizens, which we aim to shed light on in the following sections.

\section{The Monetary Dialogue and the ECB's Accountability in the Crisis}

To assess the workings of accountability in the MD, we first make a number of observations about the exchanges of opinion between parliamentarians and the successive ECB presidents Jean-Claude Trichet and Mario Draghi. These are revealed by examining salient discussions in the verbatim transcripts of the dialogue over the seventh legislature. We then proceed with analysing the views MEPs have about the MD in relation to their participation in - and the perceived effects of - the dialogue. Here, we rely on data from an own survey posed to MEPs in the ECON committee.

\footnotetext{
${ }^{5}$ One may note that the econometric estimates produced by means of the GARCH model provide evidence for short-term effects during the eurozone crisis, based on day-to-day developments. They thus do not rule out hypothetical longer-term benefits of the MD for monetary policy efficiency.
} 


\section{Style and Content of the Dialogue}

The seventh parliament has covered the full unfolding of the euro crisis. During its term, the MD has taken place 20 times. Initially, the ECB was represented by President Jean-Claude Trichet, after 1 November 2011 by Mario Draghi. Thus, this parliament has seen many transformations of monetary policy and its environment and that would have justified thorough scrutiny. The style of interactions appears to have changed quite significantly during the five-year period. In the early days, MEPs asked Mr Trichet questions in a mostly submissive fashion, to which he replied with broad generalities. Dwyer and Clarida (2012, p. 38) have argued that this was a deliberate policy, with the ECB purportedly realizing that 'a certain level of opaqueness allows more flexibility and credibility in non-standard measures' as well as seeking to limit its own exposure to 'speculative attacks'. MEPs seemed to go along with this philosophy. However, at the later stages of the crisis it became clear that markets and the public needed clarity and guidance, not opacity. By 2013, the parliament's exchanges with Mr Draghi had become the expression of a more emancipated working relationship, where both sides of the dialogue were partners, even if in different roles, trying to resolve the euro area's problems (Torres, 2013).

Some of the subjects under discussion re-appeared in almost every session: economic growth, price stability (in this order), fiscal policy, internal and external competitiveness, financial and macro prudential supervision. Others clearly gained prominence with the intensification of the crisis: liquidity provision and yield spreads, institutional innovations (EFSF (European Financial Stability Facility), ESM (European Stability Mechanism), fiscal compact, SMP (Securities Markets Programme), long-term refinancing operation (LTRO), OMT), even constitutional issues (Van Rompuy Report, exit from the euro area) and of course austerity. While the discussions with President Trichet covered broad macroeconomic issues and remained more superficial, the dialogue with President Draghi has become more operational and technical. Trichet frequently stopped technical questions by referring to the ECB's mandate; Draghi is willing to answer even hypothetical questions as this example shows:

I still claim that our LTROs have been quite timely and, all in all, successful. If the only thing we have achieved is buying time - and it is not the only thing - that would in itself be an extraordinary success. Think about what could have happened: EUR 230 billionplus of bank bonds due in the first three months of this year and more than that in sovereign funding due, and markets completely closed. We avoided that. (European Parliament, 2012a)

However, if the purpose of the MD is to hold the ECB to account, there have been some spectacular mishaps. On 9 March 2009 (the last session of the previous parliament), the global financial crisis had already thrown the world into its deepest recession since World War II, ${ }^{6}$ but the ECB president and MEPs still seemed to be in relatively optimistic mood, believing in the euro area's resilience after the earlier important interest rate cuts. Nevertheless, Trichet already pointed at three subjects which were to dominate the next five years: asset price dynamics, mainly in the housing market, internal macroeconomic imbalances and the need for macro prudential supervision (European Parliament,

\footnotetext{
${ }^{6}$ On 22 March 2010, Trichet even ventured to say: 'we have had to cope with the worst crisis since World War II, perhaps even potentially the worst crisis since World War I' (European Parliament, 2010).
} 
2009). John Purvis, an MEP for the European People's Party group (who did not return to the next parliament), asked the pertinent question whether there was a contingency plan 'in case one of the member states really got into very substantial difficulties and was unable to fund its public debt?' (European Parliament, 2009). Trichet replied at the time that the idea of one member country creating a problem for the whole euro area was 'absolutely absurd' (European Parliament, 2009). One year later, he had to admit that even a country representing only a tiny fraction of the euro area GDP has an influence on the whole of the eurozone. He concluded that 'we do indeed share a common destiny and that all of us therefore - I am talking of the governments here - are justified in exercising this common responsibility, this collective responsibility which is essential' (European Parliament, 2010). Yet, no MEP asked Trichet how he had come to this new conclusion. Maybe it was too obvious in the changed environment, but the incident shows that mistakes in assessment are often shared by the scrutinized as well as by the scrutinizer.

Another example for insufficient scrutiny is what may have been the biggest blunder in the short history of the ECB. On 7 April 2011, in the midst of the euro crisis, the governing council increased the policy interest rate by 25 basis points, because inflation had shot up above the 2 per cent target and economic growth had been forecasted between 1.5 and 2.3 per cent (ECB, 2011). Speaking to MEPs, Trichet justified the decision by saying that the governing council 'sees the monetary policy stance as still accommodative' (European Parliament, 2011a). At the same time, he supported fiscal consolidation. Not surprisingly, demand collapsed after the usual two-quarter lag and the euro area fell again into recession, while in the United States, in contrast, fiscal consolidation was delayed and growth was sustained. The astonishing fact is that at the first MD after the rate hike, on 20 June 2011, not even one MEP questioned or criticized the interest decision. Instead, MEPs kept riding their hobby horses on rating agencies and talking of constitutional quantum leaps (European Parliament, 2011a). While one is always smarter with hindsight, the case shows that the ECB can at times get away with little accountability by the EP. When the ECB corrected the mistake a few months later, President Draghi was not challenged either.

Nevertheless, the ECB president explained more clearly by then the purpose of unconventional monetary policies which had the primary objective of helping 'restore the credit process for households and for small and medium-sized companies', as this was necessary 'to avoid an even more significant weakening in growth than we have already had' (European Parliament, 2011b). He also indicated that unconventional policies were different from other central banks like in the United States or the UK, because 'banks represent $80 \%$ of the lending to the euro area' (European Parliament, 2011b). Importantly, the new ECB president responded more clearly to policy concerns regarding the ECB's mandate expressed by MEPs. In July 2012, Draghi pointed out that the bank's monetary analysis indicated price stability over the medium term and stressed that price stability always mattered 'in both directions, upwards and downwards' (European Parliament, 2012b). He also acknowledged criticism of austerity by agreeing that it had indisputable contractionary effects in the short term, all the while asking ' $\ldots$ is this avoidable? Was the previous situation sustainable? Basically there was no choice' (European Parliament, 2011b).

In summary, the protocols of the MD convey a sense of progress towards a clearer communication by the ECB and somewhat more pertinent questions by MEPs, although 
there undoubtedly remains potential for further improvement. For the most part, this finding is attributable to the central bank and its new president Mario Draghi seeking a strategic relationship with the ECON committee during the crisis (cf. Torres, 2013), especially with respect to furthering the understanding of unconventional policy measures and inviting more detailed discussions, thus moving towards a higher degree of democratic accountability rather than merely lecturing passive MEPs. We therefore consider the exchanges in the MD to provide evidence in favour of hypothesis $\mathrm{H} 2$.

\section{How MEPs Evaluate the Monetary Dialogue}

Political accountability is a multi-level process. While the EP holds the ECB to account, electors do likewise with MEPs. This section reports the performance of the members of ECON during the seventh parliament and presents answers to a questionnaire submitted to all members of the committee inquiring, amongst others, how they assess the dialogue themselves. The seventh parliamentary ECON committee had 99 members, of whom 50 were full members and 49 were substitutes (with some participants having been replaced over time, thus marking a total of 110 MEPs). Of these, 43 never asked a question during the five-year term of the parliament. With respect to those who have intervened, the average number of questions per session asked by all MEPs was 22.5. In general, the frequency of interventions by MEPs represented the strength of their parliamentary group in the parliament, although ALDE outperformed other groups and S\&D underperformed. The ECON committee was made up of 67 per cent euro area and 32 per cent non-euro area MEPs. Members from the euro area asked 79 per cent of all questions addressed to the ECB president. Of these, representatives from Germany, France and Spain were the most active participants in the dialogue. Members from Greece, Ireland and Luxemburg also participated more than their overall weight in the parliament or the ECON would reflect, while MEPs from Italy, the Netherlands and Finland have participated least in the dialogue relative to the number of seats they have in ECON.

Out of the 99 committee members, 20 responded to our questionnaire. While this indicates a sizeable non-response rate at face value, this is to a certain extent mitigated by the fact that the vast majority of responses received were from full members of the committee (16 out of 20 responses, with 50 full members in total), which inarguably constitute the more relevant group of MEPs in the ECON. In addition, the responses to our questionnaire cover roughly the different frequencies of questions asked by ECON members, with the only highly underrepresented groups of MEPs being those that have asked zero or one question during the entire course of the seventh parliament. It should be fair to state that these form quite clearly the less noteworthy part of the monetary dialogue. This is illustrated in Figure 2. On the horizontal axis we report the number of questions per MEP ('frequency'); on the vertical axis we show how many MEPs correspond to each frequency and compare this to how many of them responded to our questionnaire.

The questionnaire results reveal the following opinions from members of ECON. Most MEPs (75 per cent) indicate they participate regularly or always in the dialogue and so do 85 per cent of their staff. More importantly, and pointing to our question of accountability, all respondents deem the MD (at least sometimes) useful for themselves (see Table 2). In addition, 85 per cent feel always or regularly well prepared for the dialogue, while 74 per cent find the academic papers produced beforehand by the expert group to be of use. 
Figure 2: MEP Participation in Monetary Dialogue and Responses to Questionnaire

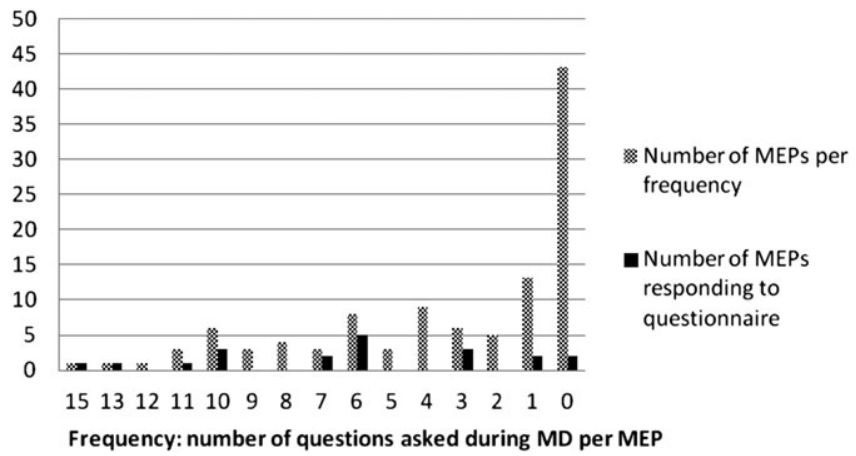

Table 2: 'Have You Found the Meetings Useful for Yourself?'

\begin{tabular}{lccl}
\hline & 'Always' & 'Sometimes' & 'Never' \\
\hline Total number & 8 & 8 & 0 \\
Per cent & $50 \%$ & $50 \%$ & $0 \%$ \\
EPP & & & $0 \%$ \\
S\&D & $31 \%$ & $0 \%$ & $0 \%$ \\
ALDE & $6 \%$ & $19 \%$ & $0 \%$ \\
Greens-EFA & $13 \%$ & $0 \%$ & $0 \%$ \\
ECR & $0 \%$ & $19 \%$ & $0 \%$ \\
EFD & $0 \%$ & $6 \%$ & $0 \%$ \\
\hline
\end{tabular}

EPP = European People's Party, S\&D = Progressive Alliance of Socialists and Democrats, ALDE = Alliance of Liberals and Democrats for Europe, Greens-EFA = The Greens-European Free Alliance, ECR = European Conservatives and Reformists, EFD = Europe of Freedom and Democracy

Table 3: 'Do You Think the Monetary Dialogue has Made a Difference for the Management of the Euro Crisis?'

\begin{tabular}{lccc}
\hline & Yes' & 'No' & 'Don't know' \\
\hline Total number & 5 & 11 & 4 \\
Per cent & $25 \%$ & $55 \%$ & $20 \%$ \\
& & & \\
EPP & $20 \%$ & $10 \%$ & $5 \%$ \\
S\&D & $0 \%$ & $15 \%$ & $5 \%$ \\
ALDE & $0 \%$ & $10 \%$ & $5 \%$ \\
Greens-EFA & $0 \%$ & $10 \%$ & $5 \%$ \\
ECR & $5 \%$ & $0 \%$ & $0 \%$ \\
EFD & $0 \%$ & $5 \%$ & $0 \%$ \\
NI & $0 \%$ & $5 \%$ & $0 \%$ \\
\hline
\end{tabular}

EPP = European People's Party, S\&D = Progressive Alliance of Socialists and Democrats, ALDE = Alliance of Liberals and Democrats for Europe, Greens-EFA = The Greens-European Free Alliance, ECR = European Conservatives and Reformists, EFD = Europe of Freedom and Democracy, NI = Non-Inscrits 
Figure 3: 'Do You Think the ECB Takes the Views of the EP into Consideration when Making Decisions?'

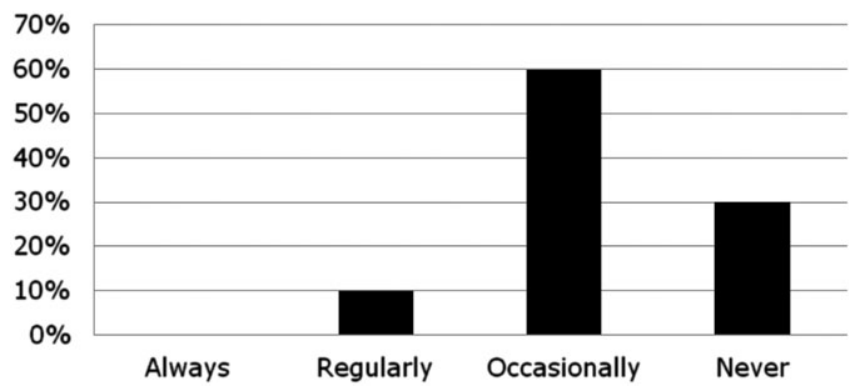

Yet, mirroring in some sense the outcome of our econometric analysis, MEPs' evaluation of the dialogue's effectiveness during the euro area crisis is mixed: most (55 per cent) do not think the dialogue has made a difference for the management of the crisis (see Table 3). As far as political ideologies come into play, a broad pattern that is discernible is that pro-European parties on the centre-right are more content with the work of the MD: they find the dialogue both more useful for themselves and for the handling of the crisis than parties on the left and Euro-sceptics.

With regard to the issue of inter-institutional co-operation, 55 per cent of respondents think that the central bank's most important partner is ECOFIN (Economic and Financial Affairs Council), while only 17 per cent think so of the parliament itself and 28 per cent of the European Council. Nonetheless, only a minority of 30 per cent would go as far as saying that the ECB does not take the views of the EP into consideration at all when making decisions (see Figure 3). What's more, all responding MEPs deem the ECB's independence to be 'a good thing' and a majority of 55 per cent think that the bank's transparency towards them is adequate. At the same time, nearly 70 per cent replied they would like to see the publication of minutes of internal deliberations - which the ECB has in the meantime started to provide (beginning with its January 2015 governing council meeting).

On the whole, what we take from our short survey exercise is that the majority of MEPs seem to express a cautious satisfaction with the work of the MD. To the extent that this provides an indication of the ECB's practice of accountability towards the ECON, this constitutes further confirmatory evidence for hypothesis $\mathrm{H} 2$.

\section{Conclusion}

The accountability of an independent central bank is important, but probably less for reasons of market efficiency than for reasons of democratic legitimacy. Nevertheless, without legitimacy the ECB will not be effective. Hence, the MD is an important pillar of the institutional architecture of Europe's economic and monetary union. Our study has shown that yield spreads in most crisis countries of the euro area have increased in the days after the dialogue, and MEPs correctly feel that the dialogue did not make a big difference for the management of the euro crisis. However, they do appreciate its role for informing and 
engaging them. Not all members of the ECON committee participate and intervene actively in the MD, but those who do feel well informed and prepared for their exchanges with the president of the ECB. The quality of these exchanges has been shown to improve during the crisis, with the ECB - in the person of its president Mario Draghi - displaying an increased readiness to discuss its unconventional monetary policy measures with MEPs. It must be noted that our study has focused on the immediate and short-term effects of discussions about monetary policy decisions in an increasingly deteriorating economic context. In how far these effects are generalizable to the pre-crisis 'normal' times and prove to be robust in the long run will need to be the work of further research. In themselves, our findings contribute to our understanding about the ways in which the euro area's supranational institutions have co-operated in battling off some of the worst repercussions of the crisis. More broadly, our results indicate that the issues of central bank communication and accountability, while necessarily demonstrating some overlap, ought to be appreciated separately. Communication and transparency are important for the transmission of monetary signals and the response by financial markets. Accountability serves to embed the institution of an independent central bank in the broader framework of democratic legitimacy. The MD has helped the ECB make some progress during the crisis with regard to the latter.

\section{Correspondence:}

Sebastian Diessner

London School of Economics and Political Science

European Institute

Houghton Street

London WC2A $2 \mathrm{AE}$

UK.

email: s.diessner@1se.ac.uk

\section{References}

Amtenbrink, F. and Van Duin, K. (2009) 'The European Central Bank before the European Parliament: Theory and Practice after Ten Years of Monetary Dialogue'. European Law Review, Vol. 34, No. 4, pp. 561-83.

Baimbridge, M., Burkitt, B. and Whyman, P. (1999) 'The Bank that Rules Europe? The ECB and Central Bank Independence'. Bruges Group Working Paper, No. 37.

Begg, I. (2006) 'Economic Policy and Institutional Transparency: The ECB'. In Oxelheim, L. (ed.) Corporate and Institutional Transparency for Economic Growth in Europe (Oxford: Elsevier), 47-70.

Born, B., Ehrmann, M. and Fratzscher, M. (2012) 'Communicating about Macroprudential Supervision - A New Challenge for Central Banks'. International Finance, Vol. 15, No. 2, pp. 179-203.

Born, B., Ehrmann, M. and Fratzscher, M. (2014) 'Central Bank Communication on Financial Stability'. Economic Journal, Vol. 124, No. 577, pp. 701-34.

Buiter, W.H. (2006) 'How Robust is the New Conventional Wisdom in Monetary Policy? The Surprising Fragility of the Theoretical Foundations of Inflation Targeting and Central Bank Independence'. CEPR Discussion Paper, No. 5772.

Collignon, S., Esposito, P. and Lierse, H. (2013) 'European Sovereign Bailouts, Political Risk and the Economic Consequences of Mrs. Merkel'. Journal of International Commerce, Economics and Policy, Vol. 4, No. 3, pp. 80-105. 
Crowe, C. and Meade, E.E. (2008) Central Bank Independence and Transparency: Not Just Cheap Talk (Part 1). VoxEU - CEPR's Policy Portal. Available at «http://www.voxeu.org/article/central-bank-independence-and-transparency-not-just-cheap-talk-part-1».

De Grauwe, P. (2012) Economics of Monetary Union (9th edition) (Oxford: Oxford University Press).

De Grauwe, P. and Gros, D. (2009) 'Accountability and Transparency in Central Banking'. Study requested by European Parliament, IP/A/ECON/ST/2008 17.

Dwyer, G.P. and Clarida, R.H. (2012) 'A Comparative Study of Global Central Bank Independence and Transparency: Lessons Learned from the Crisis'. Paper presented at Federal Reserve Bank of New York Capstone Project, spring.

Ehrmann, M. and Fratzscher, M. (2007) 'Communication by Central Bank Committee Members: Different Strategies, Same Effectiveness?'. Journal of Money, Credit and Banking, Vol. 39, No. 2-3, pp. 509-41.

Ehrmann, M. and Fratzscher, M. (2013) 'Dispersed Communication by Central Bank Committees and the Predictability of Monetary Policy Decisions'. Public Choice, Vol. 157, No. 1, pp. 223-44.

Eijffinger, S.C.W. and Geraats, P.M. (2006) 'How Transparent are Central Banks?'. European Journal of Political Economy, Vol. 22, No. 1, pp. 1-21.

Eijffinger, S.C.W. and Mujagic, E. (2004) 'An Assessment of the Effectiveness of the Monetary Policy Dialogue on the ECB's Accountability and Transparency: A Qualitative Approach'. Intereconomics, Vol. 39, No. 4, pp. 190-203.

Enders, W. (2004) Applied Econometric Time Series (Hoboken, NJ: Wiley).

European Central Bank (2011) Introductory Statement to the Press Conference, 7 April 2011 (Frankfurt: ECB Directorate General Communications and Language Services).

European Central Bank (2012) Verbatim of the Remarks Made by Mario Draghi at the Global Investment Conference in London, 26 July 2012 (Frankfurt: ECB Directorate General Communications and Language Services).

European Central Bank (2014) 'The ECB’s Forward Guidance'. Monthly Bulletin, April, pp. 65-73.

European Parliament (1998) 'Resolution on Democratic Accountability in the Third Phase of EMU'. Official Journal of the European Union, C 138, 4 May.

European Parliament (2009) Full text of the hearing: Monetary Dialogue with Jean-Claude Trichet, Brussels, Monday, 30 March (Brussels: European Parliament).

European Parliament (2010) Full text of the hearing: Monetary Dialogue with Jean-Claude Trichet, Brussels, Monday, 22 March (Brussels: European Parliament).

European Parliament (2011a) Full text of the hearing: Monetary Dialogue with Jean-Claude Trichet, Brussels, Thursday, 30 June (Brussels: European Parliament).

European Parliament (2011b) Full text of the hearing: Monetary Dialogue with Jean-Claude Trichet, Brussels, Monday, 19 December (Brussels: European Parliament).

European Parliament (2012a) Full text of the hearing: Monetary Dialogue with Mario Draghi, Brussels, Wednesday, 25 April (Brussels: European Parliament).

European Parliament (2012b) Full text of the hearing: Monetary Dialogue with Mario Draghi, Brussels, Monday, 9 July (Brussels: European Parliament).

Geraats, P.M. (2008) 'ECB Credibility and Transparency'. European Economy Economic Papers, No. 330.

Gersbach, H. and Volker, H. (2008) 'Should the Individual Voting Records of Central Bankers be Published?'. Social Choice and Welfare, Vol. 30, No. 4, pp. 655-83.

Goodhart, C.A.E. (1987) 'Why do Banks Need a Central Bank?'. Oxford Economic Papers, Vol. 39, No. 1, pp. 75-89.

Gros, D. (2004) '5 Years of Monetary Dialogue'. CEPS Briefing Paper, April.

Jabko, N. (2003) 'Democracy in the Age of the Euro'. Journal of European Public Policy, Vol. 10, No. 5, pp. 710-39. 
Jansen, D.-J. and de Haan, J. (2007) 'Were Verbal Efforts to Support the Euro Effective? A HighFrequency Analysis of ECB Statements'. European Journal of Political Economy, Vol. 23, No. 1 , pp. 245-59.

Majone, G. (2001a) 'Nonmajoritarian Institutions and the Limits of Democratic Governance: A Political Transaction-Cost Approach'. Journal of Institutional and Theoretical Economics, Vol. 157, No. 1, pp. 57-78.

Majone, G. (2001b) 'Two Logics of Delegation: Agency and Fiduciary Relations in EU Governance'. European Union Politics, Vol. 2, No. 1, pp. 103-22.

Pisani-Ferry, J. and von Weizsäcker, J. (2009) 'Can a Less Boring ECB Remain Accountable?'. Bruegel Policy Contribution, No. 11.

Pollack, M.A. (1997) 'Delegation, Agency, and Agenda Setting in the European Community'. International Organisation, Vol. 51, No. 1, pp. 99-134.

Rosa, C. and Verga, G. (2007) 'On the Consistency and Effectiveness of Central Bank Communication: Evidence from the ECB'. European Journal of Political Economy, Vol. 23, No. 1, pp. 146-75.

Scharpf, F.W. (1999) Governing in Europe: Effective and Democratic? (Oxford: Oxford University Press).

Schonhardt-Bailey, C. (2013) Deliberating American Monetary Policy: A Textual Analysis (Cambridge, MA: MIT Press).

Sibert, A. (2005) The European Parliament's Monetary Dialogue with the ECB and its Panel of Experts (Brussels: European Parliament).

Sibert, A. (2010) 'Accountability and the ECB'. Paper presented at the 38th Economics Conference of the Central Bank of Austria, Vienna, 2 June.

Stasavage, D. (2003) 'Transparency, Democratic Accountability and the Economic Consequences of Monetary Institutions'. American Journal of Political Science, Vol. 47, No. 3, pp. 389-402.

Torres, F. (2013) 'The EMU's Legitimacy and the ECB as a Strategic Political Player in the Crisis Context'. Journal of European Integration, Vol. 35, No. 3, pp. 287-300.

Vayid, I. (2013) 'Central Bank Communications Before, During and After the Crisis: From OpenMarket Operations to Open-Mouth Policy’. Bank of Canada Working Paper, No. 41.

Woodford, M. (2005) 'Central-Bank Communication and Policy Effectiveness'. Paper presented at the Federal Reserve Bank of Kansas City Symposium, Jackson Hole, 25-27 August.

Wyplosz, C. (2005) 'European Monetary Union: The Dark Sides of a Major Success'. Economic Policy, Vol. 21, No. 46, pp. 207-61.

\section{Supporting Information}

Additional supporting information can be found in the online version of this article at the publisher's web-site. 